\title{
Radical Right-Wing Parties Facing the Wall of the Local? The Vlaams Belang and Local Elections (1982-2018)
}

\author{
Pascal Delwit \\ Université libre de Bruxelles, Bruxelles, Belgium \\ Email: pdelwit@ulb.ac.be
}

How to cite this paper: Delwit, P. (2019). Radical Right-Wing Parties Facing the Wall of the Loca? The Vlaams Belang and Local Elections (1982-2018). Open Journal of Political Science, 9, 631-651.

https://doi.org/10.4236/ojps.2019.94039

Received: August 28, 2019

Accepted: October 5, 2019

Published: October 8, 2019

Copyright $\odot 2019$ by author(s) and Scientific Research Publishing Inc. This work is licensed under the Creative Commons Attribution International License (CC BY 4.0).

http://creativecommons.org/licenses/by/4.0/

\section{(c) (i) Open Access}

\begin{abstract}
Many radical right-wing parties have marked significant growth in the last 20 years. This spectacular dynamic has received thorough attention from the scientific community. Their electoral performance has most often been analysed at a national level. Analysis at sub-national levels is rare. This paper analyses the performance of the Vlaams Belang (Flemish Interest) in local elections in Belgium between 1982 and 2018. Our analysis shows that the Vlaams Belang was able to overcome all institutional and political barriers in order to compete successfully at this level. At the same time, we find that the institutionalisation process at the local level is not a predictor of the ensuing electoral result for the party. On the contrary, the local electoral result correlates to the national curve and the global image of the party. In this dynamics, local elections could lead to different outcomes for the Vlaams Belang. The 1988 and 2018 local elections paved the way to a larger political development. On the contrary, the 2006 local elections led to a sharp political and electoral decline.
\end{abstract}

\section{Keywords}

Radical Right, Party Politics, Belgian Politics, Vlaams Belang, Local Elections, Far Right, Radical Right-Wing Parties

\section{Introduction}

Many Radical Right-Wing Parties have made significant progress in the last 20 years. This spectacular dynamic has received exceptional attention from the scientific community (Akkerman, de Lange, \& Rooduijn, 2016; Betz, 1994; Heinisch \& Mazzoleni, 2016; Ignazi, 2003; Kitschelt, 1997; Mudde, 2017; Muis \& Immerzeel, 
2017). The way this family of parties is described, their electorates studied, the sources of this breakthrough, the impacts on partisan systems are all questions that have produced a very significant amount of work. In this context, the Vlaams Belang (Flemish Bloc) has in the recent past been neglected. The Vlaams Belang, a Far-Right Party in the Flemish part of Belgium, belongs-like the French National Front (FN, today National Rally) or the Freedom Party of Austria (FPÖ) - to the first wave (Ivaldi, 2019) of the renaissance of Radical European Rights. As such, it had been the subject of sustained primary attention. Nevertheless, against the general trend, the Vlaams Belang has lost much of its electoral and political influence over the past 10 years. The ambition of this paper is to go back and focus on this party by analysing it from the perspective of Local Elections.

Regarding elections, Radical Right-Wing Parties are most often analysed on a national level, legislative and European elections in particular. Analysis at subnational levels is less usual. The comparative perspective is also more complex, in that the institutional and political importance of sub-national levels differs significantly from State to State. Voter turnout is consistently lower than in first-order elections.

In Belgium, two dimensions make party analysis in local competition particularly salient. Firstly, both citizens and political parties deem the municipal level very important. The interweaving of political staff in their local and national functions is tight, and the function of mayor is esteemed and much sought after. Secondly, as with all other elections in Belgium, voting at local elections is compulsory. This institutional constraint facilitates comparisons of party performance at different elections. Indeed, the comparison between the electoral results of the parties is not affected by very different levels of voter turnout due, for example, to differential abstentionism (Dolez, 2004) ou to abstentionism related to the "second-order" character of an election (Reif \& Schmitt, 1980). Whatever the election in Belgium, the average electoral turnout is between $88 \%$ and $91 \%$.

\section{From the Vlaams Blok to the Vlaams Belang}

When the Vlaams Blok was being born, assigning this party to the Extreme Right or Radical Right is probably not appropriate. Its first public and electoral appearance took place in the 1978 national elections. The election was held following the failure of a compromise-the Egmont Pact-on the establishment of new regions in Belgium. Under pressure from several social groups in Flanders, from some of the Flemish Christian Democrats and from several influential columnists, Belgian Prime Minister Leo Tindemans had foiled the agreement. At the Flemish Regionalist Party-the Volksunie (VU, People's Union)—which participates in the government, this compromise had also caused strong tensions. On 28 May 1977, it had been supported by only two-thirds of the Party Council members (Govaert, 1992: p. 5). Several of the opponents then abandoned the party, which they also considered too cultural liberal (Kitschelt, 1988). Separately, two groups created another political party. Karel Dillen established 
the VNP (Vlaams Nationale Partij, Flemish National Party) on 2 October 1977. Dillen embodied the most right-wing current of the Volksunie and its most extra-institutional wing. Most of the VNP cadres were located in the Antwerp province, the cradle of Flemingantism and of the Flemish Extreme Right in the inter-war period (De Wever, 1994). Shortly after the foundation of the VNP, Lode Claes and people close to him launched the Vlaamse Volkspartij (VVP, Flemish People's Party). A former Parliamentarian of the Volksunie, Lode Claes was one of the conservative movement figures.

The VVP was mainly present in Flemish Brabant. Despite divergent views, the two parties formed an electoral cartel for the 1978 elections, under the title "Vlaams Blok" (Flemish Blok). The results were disappointing. The Vlaams Blok reaped reasonable esteem scores at Antwerp and, to a lesser extent, in the Brabant. Yet, only Karel Dillen was elected at Antwerp; Lode Claes failed in Brussels. This mixed result and its asymmetrical translation for VNP and VVP led to the end of the cartel. The VVP ran alone in the 1979 European elections but was not successful, and it dissolved shortly afterwards. In order to welcome executives from the VVP, the VNP was transformed into the Vlaams Blok. Originally based on so-called community issues (relations between French-speaking and Dutch-speaking communities in Belgium), the Vlaams Blok gradually changed the focus of its propaganda as well as its identity towards fighting against immigration (Mudde, 2002), boosted in particular by the arrival of young professionals such as Gerolf Annemans and Filip Dewinter. Flanders' independence, as well as xenophobic and racist discourses, became the Vlaams Blok's two public leitmotifs (Swyngedouw \& Ivaldi, 2001). In 1992, the adoption of a 70-point programme to solve the problem of foreigners stood as the culmination of this approach by the Vlaams Blok (1992). This led to the departure or exclusion of executives who believed the party's identity was strictly linked to the promotion of Flemish nationalism.

Since its inception, the Vlaams Blok has had three political and electoral lives. Between 1981 and 1991, the party was mainly confined to its initial point of gravity, the province of Antwerp and even more precisely in the Antwerp municipality. The Vlaams Blok did not really manage to deploy outside this Antwerp core. A movement was underway in the 1987 legislative elections, but remained elusive. For the first time, the Vlaams Blok exceeded the 100,000 vote threshold $(116,534)$. This progress was sustained in the 1989 European elections. With 241,117 votes, the Far-Right party managed to win one MEP. This progress was spectacularly achieved at November 1991 legislative elections, which ushered in a new phase in the party's history.

On this election, dubbed a Black Sunday (Mudde, 2002: p. 89), the Vlaams Blok gathered more than 400,000 votes. For the first time, it was ahead of the Volksunie. From that date on, the Vlaams Blok has continued to grow from an organisational, electoral, cultural and political point of view.

From an organisational point of view, the party has seen a significant increase in its membership. In four years, the party climbed from 4682 members to 9322 , 
and recorded a further jump to 17,544 members in 2002; 21,942 in 2005 and 25,090 the following year (see Table 1 ).

During the 90s, the Vlaams Blok became the party that largely determined the political and media agenda in Flanders and Belgium. Electoral progress continued from one election to the next. On the Flemish scale, the party obtained $12.3 \%, 15.3 \%$ and $18 \%$ at the 1995, 1999 and 2003 legislative elections. A pinnacle was reached in the 2004 regional elections. On that occasion, the party garnered no less than $24 \%$ of the votes. This result was surprising in that a few weeks earlier, the Vlaams Blok had deplored the conviction of three of its NGOs being confirmed by the Ghent Court of Appeal, which presented the Vlaams Blok "as a group or association that clearly and repeatedly advocates discrimination" (Brems, 2006: p. 705).

In so doing, the conviction of the Vlaams Concentratie (Flemish Concentration), the Nationalistisch Vorming Instituut (National Training Institute) and the Nationalistische Omroep Stichting (Nationalist Broadcasting Foundation) were confirmed. However, contrary to expectations, this ruling did not have a negative impact on the Vlaams Blok. Quite the contrary: the electoral leap was noticeable, with 5.9 extra percentage points. A few months later, however, the Vlaams Blok changed its name to Vlaams Belang (Flemish Interest) to get rid of the sultry image associated with the Vlaams Blok.

Several elements make it possible to grasp this growth. Territorially, the Vlaams Blok continued to climb in the area it scores highest, the province of Antwerp. In 2004, the Vlaams Blok took 30\% of the votes and established itself as the leading political party. At the same time, the party managed to expand outside this enclave (see Table 2). Little by little, the Vlaams Blok made progress

Table 1. The Vlaams Blok (Vlaams Belang) party membership.

\begin{tabular}{llllll}
\hline 1979 & 824 & 1993 & 6131 & 2007 & 25,000 \\
1980 & 1231 & 1994 & 7372 & 2008 & 23,850 \\
1981 & 1607 & 1995 & 9,322 & 2009 & 22,500 \\
1982 & 2435 & 1996 & 10,038 & 2010 & 19,528 \\
1983 & 2821 & 1997 & 10,048 & 2011 & 17,139 \\
1984 & 3269 & 1998 & 11,218 & 2012 & 16,433 \\
1985 & 3698 & 1999 & 14,424 & 2013 & 17,139 \\
1986 & 4004 & 2000 & 17,167 & 2014 & 17,255 \\
1987 & 4213 & 2001 & 17,356 & 2015 & 17,789 \\
1988 & 2458 & 2002 & 17,544 & 2016 & 17,986 \\
1989 & 2630 & 2003 & 16,860 & 2017 & 18,153 \\
1990 & 3452 & 2004 & 17,892 & 2018 & 18,311 \\
1991 & 4069 & 2005 & 21,942 & & \\
1992 & 4682 & 2006 & 25,090 & & \\
\hline
\end{tabular}

Source: Data provided by the Vlaams Belang Central Office and https://www.projectmapp.eu. 
Table 2. Electoral Results of the Vlaams Blok/Vlaams Belang from 1978 until 2014 at National $(\mathrm{N})$, Regional $(\mathrm{R})$ and European elections (E).

\begin{tabular}{|c|c|c|c|c|c|c|c|}
\hline & Flanders & $\begin{array}{c}\text { Brussels } \\
\text { (Halle-Vilvoorde) }\end{array}$ & $\begin{array}{l}\text { Flemish } \\
\text { Brabant }\end{array}$ & Antwerp & $\begin{array}{l}\text { Western } \\
\text { Flanders }\end{array}$ & $\begin{array}{c}\text { Eastern } \\
\text { Flanders }\end{array}$ & Limburg \\
\hline $1978(\mathrm{~N})$ & 2.0 & 1.9 & 1.8 & 2.9 & 1.2 & 2.1 & 1.2 \\
\hline $1981(\mathrm{~N})$ & 1.4 & 0.9 & 0.9 & 3.1 & 1.0 & - & 0.8 \\
\hline $1984(\mathrm{E})$ & 2.0 & 1.2 & 1.2 & 3.3 & 1.2 & 1.9 & 1.0 \\
\hline $1985(\mathrm{~N})$ & 2.2 & 1.4 & 1.6 & 4.0 & 1.1 & 1.8 & 0.9 \\
\hline $1987(\mathrm{~N})$ & 3.0 & 1.5 & 2.2 & 5.9 & 1.4 & 2.2 & 1.3 \\
\hline $1989(\mathrm{E})$ & 6.3 & 4.4 & 4.3 & 11.7 & 2.9 & 5.0 & 3.2 \\
\hline $1991(\mathrm{~N})$ & 10.4 & 3.9 & 9.0 & 16.7 & 5.6 & 9.2 & 7.0 \\
\hline $1995(\mathrm{~N})$ & 12.3 & 3.7 & 10.1 & 18.3 & 8.1 & 11.3 & 9.7 \\
\hline $1999(\mathrm{~N})$ & 15.3 & 4.1 & 13.2 & 20.9 & 11.1 & 15.4 & 12.7 \\
\hline 1999 (R) & 15.8 & 4.5 & 13.5 & 21.2 & 11.3 & 15.6 & 12.5 \\
\hline 1999 (E) & 14.7 & 3.3 & 12.4 & 19.4 & 11.4 & 14.7 & 12.5 \\
\hline $2003(\mathrm{~N})$ & 18.1 & 5.9 & 15.3 & 24.1 & 14.1 & 16.8 & 15.7 \\
\hline $2004(\mathrm{R})$ & 24.0 & 4.7 & 21.5 & 30.1 & 20.2 & 22.8 & 23.9 \\
\hline $2004(\mathrm{E})$ & 22,6 & 4.2 & 19.9 & 27.5 & 19.6 & 21.8 & 21.9 \\
\hline $2007(\mathrm{~N})$ & 19.0 & 3.1 & 16.9 & 24.1 & 14.4 & 18.6 & 20.1 \\
\hline 2009 (R) & 15.3 & 1.8 & 12.6 & 19.2 & 11.9 & 15.4 & 15.2 \\
\hline 2009 (E) & 15.6 & 2.0 & 12.8 & 19.8 & 12.3 & 15.3 & 15.6 \\
\hline $2010(\mathrm{~N})$ & 12.3 & 1.7 & 9.6 & 16.2 & 9.1 & 12.3 & 12.8 \\
\hline $2014(\mathrm{~N})$ & 5.9 & 1.1 & 4.3 & 7.0 & 4.7 & 6.2 & 6.1 \\
\hline $2014(\mathrm{R})$ & 5.9 & 0,6 & 4.4 & 7.1 & 5.1 & 6.4 & 5.9 \\
\hline $2014(\mathrm{E})$ & 6.8 & 0,8 & 5.3 & 8.0 & 6.1 & 7.0 & 6.8 \\
\hline
\end{tabular}

in the other areas and achieved convincing scores. For example, in 2004, it exceeded the $20 \%$ threshold in all Flemish provinces. The Vlaams Blok's remarkable expansion was made possible by broadening its electorate (Coffé, Heyndels, \& Vermeir, 2007; Lubbers, Scheepers, \& Billiet, 2000).

From a cultural and political point of view, the Vlaams Blok undoubtedly raised many problems on the agenda of the Flemish and Belgian political scene (Pauwels, 2011). This is true of the whole matter of security issues from a law and order perspective (Mudde, 2002) and of all issues relating to migration and the place of the Muslim faith. In the Belgian context, the so-called institutional issue should be added: the relations between linguistic communities and between regions. Influenced as it was by the French New Right, the party attached specific importance to "cultural hegemony", and did not hesitate to refer to Gramsci in order to improve its cultural influence (Spruyt, 1995).

The 2007 national election initiated a third electoral and political phase for the Vlaams Belang. Admittedly, the Flemish far right was making some progress in 
comparison with the results of the previous parliamentary elections (2003) but, with $19 \%$ of the votes, the party lost five percentage points compared to the 2004 regional elections. This shift was confirmed at the 2009 regional elections-the Vlaams Belang was down to $15.3 \%$ - and at the 2010 and 2014 legislative elections. After reaching $12.3 \%$ in 2010, the decline was sharp in 2014: minus 6.4 percentage points. With $5.9 \%$, the party scored below the first breakthrough it had achieved in the 1989 European elections. In Western Flanders and in Flemish Brabant, he did not get past the electoral threshold-5\%. Besides, in the Antwerp province, after taking $30 \%$ of the vote in 2004, the Vlaams Belang won only $7 \%$ of the vote.

How can this dynamic be understood against the backdrop of the Radical Rights' thrust in several European countries during the same period?

The exceptional breakthrough by a "new" political party in Flanders was the main reason. The Nieuw-Vlaamse Alliantie (N-VA, New Flemish Alliance) was created in 2002, following the implosion of the Volksunie (Delwit \& van Haute, 2002). Faced with the progressive current, which founded SPIRIT-Sociaal, Progressief, Internationaal, Regionalistisch, Integraal-democratisch en Toekomstgericht; Social, Progressive, International, Regionalist, Integral-democratic and Future-oriented-the N-VA embodied the conservative and Flemish option (van Haute \& Pilet, 2006). In 2003, the N-VA achieved only very modest electoral results: $4.9 \%$ in Flanders, with only one federal MP. Considering this disappointing result, the party entered into partnership with the Christian-Democrats (CD\&V). It was first tested in the 2004 regional elections and again in the 2007 federal election. Forming this cartel enabled the N-VA to expand the number of its federal and regional parliamentarians. The experiment ended in September 2008. The Flemish independentists did not endorse their poor results with the State reform and the very sensitive issue of the electoral district of Brussels-Halle-Vilvoorde; they stopped the cartel and regained full independence. Their perilous choice proved successful. In the 2009 regional elections, the Flemish Nationalist Party posted surprising results by winning $13.2 \%$ and 16 regional MPs. Better still, in the spring 2010early federal election, the N-VA emerged as the first formation in Flanders, with $28.0 \%$ of the votes cast. Four years later, it was still improving. With $32.4 \%$ of the votes at federal level, Flemish nationalists scored the most convincingly in the electoral history of Flemish nationalist organisations.

Such a collapse in favour of the N-VA can be explained by the identity(ies) of the N-VA and its less sulfurous label than the Vlaams Belang's. Itsinitial identity brought it back to the Center vs Periphery cleavage (Lipset \& Rokkan, 1967), often described as a linguistic cleavage in Belgium (Delwit, 2012). The N-VA was born out of the Volksunie; this organisation is the most faithful to the original themes and has declared its primary objective was the advent of the independence of a Flemish Republic (Nieuw-Vlaamse Alliantie, 2018: p. 2). This reference to the peripheral side is expressed not only in the Belgian context but also 
internationally. The N-VA is a member of the European Free Alliance, a European federation of parties (Delwit, 2005; Cetrà \& Liñeira, 2018) whose primary objectives are to promote decentralisation, ranging from the autonomy to the independence of the "European peoples", the cornerstone being the right to "self-determination" ". However, as of the 2010 federal election, a second identity feature emerged: the party's extremely neo-liberal position on socio-economic issues. It asserts itself in opposition to the government led by the socialist Elio Di Rupo. In 2014, the N-VA campaign was above all anti-socialist, marked by strong hostility to public regulation in economic and social affairs, and to the role of intermediary actors such as trade unions. Such positioning on the owner side of the owner vs worker cleavage has become an identifier and has been confirmed in the way of exercising public policies. Finally, the N-VA has recently revealed a third identity reference, which of a very ethnocentric party, focused on Law and Order themes (Bennett \& Tuchfarber, 1975). Adam and Deschouwer (2016) showed how the N-VA evolved in its restrictive approach to immigration or asylum seekers. Moreover, from 2009 and 2010 onwards, some N-VA executives' comments bordered on xenophobia. This rhetoric was then interpreted precisely as the party's desire to attract an electorate that opted for the Vlaams Blok and then the Vlaams Belang. This operation seemed necessary to achieve central objectives: to win the Antwerp mayorship or to make the N-VA unavoidable after the federal and regional elections in spring 2014.Over time, what appeared only as language elements of the party's most right-wing personalities actually proved central. The N-VA has gradually emerged as a political formation promoting organic nationalism (Sternhell, et al., 1989) or identity nationalism (Müller, 2016), for which rejection of the other's figure has become nodal. In this respect, the behaviour of the former Secretary of State for Asylum and Migration, Theo Francken, has highlighted a neo-conservative, even reactionary and ethnocentric vision. Emblematically, the party agreed to sit at the European Parliament as a member of the European Conservatives and Reformists Group (ECR) (Brack, 2018). Tis group includes the British Conservative and Unionist Party but, above all, some reactionary or nationalist parties, such as Law and Justice (PiS) in Poland and the Civic Democratic Party (ODS) in the Czech Republic, or even Far-Right Parties, such as the Danish People's Party (DF), the Swedish Democrats (SD) and the True Finns Party (PerusS). In recent times, party leader Bart De Wever has semantically borrowed from two schemes and paths followed by several Radical Right-Wing Parties, namely Welfare Chauvinism (Ketola \& Nordensvard, 2018; de Koster, Achterberg, \& van der Waal, 2013); and wiggling the scarecrow of the alleged promotion of open borders by left-wing parties. "True" nationals must be the sole beneficiaries of Social security benefits, which can only be perpetuated within this strict configuration, or else disappear ${ }^{2}$.

${ }^{1}$ http://www.e-f-a.org/about-us/.

${ }^{2}$ Bart De Wever, "La gauche doit choisir entre des frontières ouvertes et l'Etat providence", Le Soir, 25 janvier 2018. 


\section{Local Elections in Belgium}

Since the birth of the Belgian State, local elections have had considerable influence on political life. Over time, particularly with the extension of the right to vote, this salience has been perpetuated. Three main elements make it possible to grasp how important it is. The first stems from the historical weight of municipalities in the construction of united provinces by the State. Very early on, elites and then citizens affirmed their strong feeling of attachment to their municipalities, which is sometimes based on mistrust towards the centre. The second refers to the importance of municipalities in the institutional landscape. They have existed since independence and potentially have competences in a great number of fields: economic development, education, spatial planning, security of property and people, mobility, social assistance. In the contemporary period, this panel of prerogatives is articulated around the action and supervision of regions. Yet the regional institutions themselves are made up of many municipalists. Finally, many forms of plural political mandates are allowed in Belgium. The figure of the Mayor-MP or Deputy Mayor-MP is an important figure. Historically, Flemish Christian Democrats and French-speaking Socialists have exerted great political influence through their local presence and their figures as Mayors. Though enjoying a status that is much more modest today, the Flemish Christian Democrats are still the largest popular party at a local level.

For this reason, the new parties cannot snub local elections if they wish to continue to exist. Yet, for any new party, participation in communal elections proves much more difficult in submitting a list than at the federal national level and, since 1995, at a regional level. The number of constituencies is much larger. This, therefore, requires both a relatively large number of members likely to stand as candidates, as well as middle managers able to lead the lists and speak for the party in communal councils. Such necessities are already not easy for centripetal parties to meet. They are even more difficult for parties with a very strong and explosive ideological profile. The process of joining an Extreme Right-Wing Party is fraught with very negative connotations and can prove costly regarding family, professional or neighbourhood relations (van Haute \& Gauja, 2015). And, the process of running for such a party increases the potential for such "costs" (Klandermans \& Mayer, 2001).

Beyond such difficulties, parties are confronted with institutional constraints that are sometimes challenging to meet. Filing a list in municipal elections thus requires an alternative condition. Either an outgoing municipal Councillor sponsors the list, or a proportion of the electorate must sign a candidacy application $^{3}$. For the Vlaams Blok, any participation in the competition therefore required prior mobilization, i.e. collecting enough signatures to file the list. Sub${ }^{3} 100$ citoyens dans les communes de 20.000 habitants et plus; 50 citoyens dans les communes de 10.000 à 20.000 habitants; 30 citoyens dans les communes de 5.000 à 10.000 habitants; 20 citoyens dans les communes de 2.000 à 5.000 habitants; 10 citoyens dans les communes de 500 à 2.000 habitants; 5 citoyens dans les communes de moins de 500 habitants. CodexVlaanderen, Het Lokaal en Provinciaal Kiesdecreet van 8 juli 2011. 
sequently, the party could hope to embark on the first option. Nevertheless, the conquest of one or more for municipal councillor seat(s) is made complex by the electoral formula. Like all elections in Belgium, local elections are governed by a Proportional representation (PR). Nonetheless, unlike in federal elections, where the seat distribution divisor is the D'Hondt divisor, in communal elections, the Imperiali divisor applies. It is less favourable to lists with low and medium electoral performance (Pilet, 2007).

In this description of the framework in which a party operates in Belgian local elections, a major change occurred just before the birth of the Vlaams Blok: the number of municipalities moved. In 1976, an extensive process of merging municipalities was completed. The number of Belgian municipalities rose from 2,359 to 596, 315 of which in Flanders. This process was completed six years later by the merger of seven municipalities into the new Antwerp municipality, bringing to 308 the number of municipalities in Flanders. The merger of municipalities was crucial for small and/or new parties. It made it easier for them to participate in the elections as "constituencies" fragmentation increases the costs of submitting a list. This transformation has also increased the likelihood of winning one or more seats as magnitude increased, thereby raising the likelihood that smaller parties could win their first seat (Pilet, Freire, \& Costa, 2012). More generally, it has contributed to increased politicization (Collinge, 1981) and to the nationalization of local political life (Marien, Dassonville, \& Hooghe, 2015). In 2018, further mergers took place, bringing to 300 the number of municipalities in Flanders. For the Vlaams Blok and then Vlaams Belang, the aim was therefore to overcome all the institutional constraints of communal elections and the local political-electoral dynamic, in which the personalisation of political life is even more prominent than at national level. Did it buckle on this wall or did it overcome the obstacle and how?

\section{The Vlaams Blok (Vlaams Belang) and the Municipal Elections}

\subsection{The Coverage Rate}

Logically, the Vlaams Blok revealed a very weak coverage rate when it first participated in the 1982 municipal election. The party submitted a list in only eight percent of Flemish municipalities (25 out of 308). This submission primarily concerned its fiefdom, Antwerp, and the large municipalities of Western and Eastern Flanders. Six years later, this rate doubled (49 out of 308). Besides, in 1994, it jumped to $41.9 \%$ (129 out of 308). During this election, the Vlaams Blok filed a list in a majority of municipalities in the Antwerp province. After the Black Sunday and the confirmation of the breakthrough in the 1995 federal elections, the ability of the Flemish Far Right to present a list increased significantly. In 2000, the Vlaams Blok filed a list in most Flemish municipalities and in a very large proportion of the Antwerp municipalities (180 out of 308). In 2006, the coverage rate reached almost three quarters of Flemish municipalities (226 out 
of 308).

In line with the trend reversal in its electoral curve in national and regional elections, in 2012 the Vlaams Belang recorded a standstill in the improvement of its coverage rate. Indeed, it posted anoticeable decline. The Vlaams Belang was present in 31 fewer municipalities than in 2012 and, in Western Flanders, it even fell below the $50 \%$ of coverage rate threshold (195 out of 308). After its crushing electoral defeat in 2014, the party's presence proved even weaker in the October 2018local elections. It was present in only one out of two municipalities (151 out of 300). It remained noticeably able to cover the territory in the province of Antwerp. Not so in the other Flemish provinces, though. In the Flemish Brabant and in the Limburg, the Vlaams Belang was only present in a large third of municipalities, $35 \%$ and $38.1 \%$ respectively (Table 3 ).

These data on the capacity of the Vlaams Blok and then Vlaams Belang are at first glance evidence of the link between the national dimension of the electoral curve, the enrolment curve and the ability to build lists and submit them to voters. What about the results?

\subsection{Results at Local Elections}

In 1982, the Vlaams Blok went unnoticed. In 24 of the 25 municipalities where it was running, the party fell below $5 \%$ of the votes and, in most cases, far below

Table 3. The Vlaams Blok (Vlaams Belang) coverage rate in the local elections between 1982 and 2018.

\begin{tabular}{|c|c|c|c|c|c|c|c|}
\hline & & $\begin{array}{l}\text { Flemish } \\
\text { Brabant }\end{array}$ & Antwerp & $\begin{array}{l}\text { Western } \\
\text { Flanders }\end{array}$ & $\begin{array}{l}\text { Eastern } \\
\text { Flanders }\end{array}$ & Limburg & Flanders \\
\hline \multirow{2}{*}{1982} & Number of lists & 2 & 10 & 5 & 6 & 2 & 25 \\
\hline & Coverage Rate & $3.1 \%$ & $14.3 \%$ & $7.8 \%$ & $9.2 \%$ & $4.5 \%$ & $8.1 \%$ \\
\hline \multirow{2}{*}{1988} & Number of lists & 10 & 16 & 8 & 8 & 7 & 49 \\
\hline & Coverage Rate & $15.4 \%$ & $22.9 \%$ & $12.5 \%$ & $12.3 \%$ & $15.9 \%$ & $15.9 \%$ \\
\hline \multirow{2}{*}{1994} & Number of lists & 24 & 46 & 19 & 25 & 15 & 129 \\
\hline & Coverage Rate & $36.9 \%$ & $65.7 \%$ & $29.7 \%$ & $38.5 \%$ & $34.1 \%$ & $41.9 \%$ \\
\hline \multirow{2}{*}{2000} & Number of lists & 32 & 58 & 32 & 35 & 23 & 180 \\
\hline & Coverage Rate & $49.2 \%$ & $82.9 \%$ & $50.0 \%$ & $53.8 \%$ & $52.3 \%$ & $58.4 \%$ \\
\hline \multirow{2}{*}{2006} & Number of lists & 40 & 59 & 43 & 47 & 37 & 226 \\
\hline & Coverage Rate & $61.5 \%$ & $84.3 \%$ & $67.2 \%$ & $72.3 \%$ & $84.1 \%$ & $73.4 \%$ \\
\hline \multirow{2}{*}{2012} & Number of lists & 37 & 55 & 35 & 44 & 24 & 195 \\
\hline & Coverage Rate & $56.9 \%$ & $78.6 \%$ & $54.7 \%$ & $67.7 \%$ & $54.5 \%$ & $63.3 \%$ \\
\hline \multirow{2}{*}{2018} & Number of lists & 23 & 54 & 26 & 32 & 16 & 151 \\
\hline & Coverage Rate & $35.4 \%$ & $78.3 \%$ & $40.6 \%$ & $53.3 \%$ & $38.1 \%$ & $50.3 \%$ \\
\hline $1982-2012$ & & 65 & 70 & 64 & 65 & 44 & 308 \\
\hline 2018 & Total of communes & 65 & 69 & 64 & 60 & 42 & 300 \\
\hline
\end{tabular}

Source: Computation by the author on the basis of official results (https://vlaanderenkiest.be). 
that. Nevertheless, one exception was noteworthy. In the main Flemish municipality, Antwerp, the Far Right scored 5.2\% and won two seats. These are the only two councilors won by the party out of the 800 in competition in the municipalities where it was running (7096 in Flanders). In 1988, in the context of an increase in the number of lists, we observe two movements. In several municipalities, the party was no longer confidential. In 39 of the 49 municipalities where it was running, the Vlaams Blok achieved a result of less than 5\%, indeed; but in 9 of them, its result was in a range between $5 \%$ and $9.9 \%$. Nevertheless, the most striking element was the strengthening of the Antwerp exception. The Vlaams Blok reached $17.7 \%$, granting it 10 out of the 55 seats. This striking result enjoyed extensive media coverage and much political speculation. It was also considered as "one of the major events of this election" (Delruelle-Vosswinkel, Noël, Vanlaer, \& Vandermotten, 1989). It was a crucial channel for increasing the visibility of the Vlaams Blok and other parties' reactions (Mudde, 1995: pp. 11-12). Just a few weeks after the municipal election, the government set up an inter-ministerial committee on immigrant policy and a Royal Commission for Immigrant Policy.

In addition to the ten seats gained at Antwerp, the Vlaams Blok snatched thirteen other municipal councilors. The Vlaams Blok could, therefore, claim 23 seats out of the 1,532 seats competing in the municipalities where it presented a list (7100 in Flanders).

The progress made in the 1989 European elections and, above all, the 1991 legislative elections was clearly reflected in the 1994 municipal elections. The Vlaams Blok was running in 129 municipalities and its progress was protean. Its result was below $5 \%$ in only 33 municipalities. On the other hand, in 63 municipalities, it was between $5 \%$ and $9.9 \%$ and in 24 , between $10 \%$ and $14.9 \%$. In 8 of them, it was even in the range between $15 \%$ and $19.9 \%$. And at Antwerp, it made a further qualitative leap to $28 \%$ of the vote (18 out of 55 seats). In addition to these mandates, the Vlaams Blok won 188 seats out of the 3487 competing in the municipalities where it presented a list (7210 in Flanders). It failed to win a mandate as a municipal councilor in only 44 out of 129 municipalities (34.1\%).

In 2000, this movement grew stronger after its 1995 and 1999 electoral victories. The Vlaams Blok, now present in 180 municipalities, tended to grow there. The 5\% mark was exceeded in 171 of them (95\%). The Vlaams Blok's performance was between $5 \%$ and $9.9 \%$ in 87 of them; and between $10 \%$ and $14.9 \%$ in 51. In addition, in 20 municipalities the party reached between $15 \%$ and $19.9 \%$. The $20 \%$ threshold had now been exceeded in 13 municipalities: Beringen (20.7\%), Boom (20.8\%), Borsbeek (23.8\%), Brasschaat (20.2\%), Mechelen (25.6\%), Niel (22.1\%), Ronse (20.4\%), Schoten (24.5\%), Stabroek (23.2\%), Temse (20\%), Willebroek (21.6\%) and Wommelgem (20.3\%). At least, there is obviously Antwerp. The party climbed to $33 \%$ and took 20 out of 55 seats. Of the 4750 seats to be won in the municipalities where it was running (7276 in Flanders), the Vlaams Blok won 442 seats. 
In 2006 the communal election was scrutinized and commented on from the prism of the Vlaams Belang's ability to conquer the Antwerp mayorship. This focus on the main Flemish city can account for a partially truncated look at the Vlaams Belang performance. This was presented as a failure and even a resounding failure. This assessment was made considering the Antwerp result. In a way, this assessment was paradoxical because the Vlaams Belang obtained its best result in all local elections: $33.5 \%$ and $20 \%$ seats. Nevertheless, it was stated in line with the expectations-the possible if not the likely mayorship conquest - party leaders' unmasked disillusionment, and the fact that the socialist list overtook the Vlaams Belang (35.3\%).

Moreover, if we remove Antwerp from the analysis, the Vlaams Belang's overall performance was the best in a municipal election. In the 226 municipalities where it ran, the party was below $5 \%$ in only 2 of them. In 47, its score varied between $5 \%$ and $9.9 \%$ and in 83 of them between $10 \%$ and $14.9 \%$. Above all, in 61 municipalities its cored between $15 \%$ and $19.9 \%$ and it exceeded $20 \%$ of the votes in no less than 33 municipalities, including three where it posted more than 30\%: Aalst (22.8\%), Beringen (24.3\%), Beveren (27.1\%), Boom (29.6\%), Borsbeek (28.7\%), Brasschaat (26.1\%), Brecht (23.5\%), Hemiksem (21.8\%), Kontich (23.3\%), Leopoldsburg (22.3\%), Lier (24.2\%), Mechelen (26.5\%), Mortsel (20.6\%), Niel (29.2\%), Ninove (23.6\%), Ranst (22.5\%), Ronse (23.9\%), Rumst (22.6\%), Schelle (23\%), Schilde (21.6\%), Sint-Niklaas (26.6\%), Temse $(24.2 \%)$, Willebroek (24.2\%), Wijnegem (24.5\%), Wommelgem (23.3\%), Zoerzel (25.7\%), Zwijndrecht (22.6\%) plus Schoten (34.7\%), Stabroek (32\%) and, of course, Antwerp (33.5\%).

In terms of seat distribution, the Vlaams Blok also achieved its best performance. It failed to win seats in only 8 municipalities: Heers, Kortemark, Kruishoutem, Oosterzele, Oudenburg, Sint-Martens-Latem, Vleteren and Zuinkerke. In the other municipalities, Vlaaams Belang took 792 of the 5736 seats in the municipalities where it was present (7311 in Flanders). The 2006 communal elections, therefore, marked a major step towards institutionalisation for the Vlaams Belang at the communal level (Ignazi, 1998). Its unprecedented performance brought it exceptional scores at a local level for an Extreme Right-Wing Party and enabled it to achieve presence in most of Flanders' municipal councils. Still, the symbolic failure at Antwerp was the element mostly commented on and which struck imaginations both in and out of the party. Therefore, as an inverted mirror of the 1988 communal election, this election marked the beginning of the Vlaams Belang's declining influence. The results of the 2007 federal election were lower than scores at the 2004 regional election. Moreover, the 2009 regional and 2010 federal elections confirmed this trend. Faced with this reversal, the Vlaams Belang went to the 2012 municipal elections on stand-by. Its coverage rate remained high but immediately reflected the Vlaams Belang's reversal. Electorally, the movement was more impressive. Compared to 2006, the decline was striking. In the 180 municipalities in which it competed, the party no longer 
exceeded $5 \%$ in 52 of them. In 117, it won between $5 \%$ and $9.9 \%$ of the votes. The Vlaams Belang scored between $10 \%$ and $14.9 \%$ in only 24 municipalities. Above all, it went beyond $15 \%$ in only two municipalities, namely Grimbergen (17\%) and Ninove (26.5\%). In this context, Antwerp symbolized the extent of the decline. The Vlaams Belang went from $33.5 \%$ to $10 \%$ (5 seats out of 55 ). For the Flemish Extreme Right, the political consequence was major. The number of seats taken by the party fell drastically. The Vlaams Belang only took 214 seats out of the 5235 in the municipalities where it competed (7460 in Flanders). In 75 municipalities, it did not obtain any mandates. This disastrous election was followed two years later by the catastrophic 2014 election.

In October 2018, the communal election has been the first election since the 2014 debacle. A few months earlier a new major electoral sequence-federal, regional and European elections in May 2019-this election was a test. The difficulties the Vlaams Belang faced in the contemporary period were immediately corroborated: the Vlaams Belang only managed to submit a list in half of Flemish municipalities. Nevertheless, and importantly, this further decline in coverage rate did not anticipate the dynamics of the overall result. Indeed, just as in the provincial election that took place on the same day (Delwit, 2019), the Vlaams Belang recovered. In the 151 municipalities where it ran, the Vlaams Belang achieved a minimum score-less than 5\%-only in 5 of them. In 77, it was between $5 \%$ and $9.9 \%$. At the same time, it was in a range between $10 \%$ and $14.9 \%$ in 55 municipalities and exceeded $15 \%$ in 14 municipalities, including four that scored above 20\%: Aalst (17.3\%), Buggenhout (18.1\%), Dendermonde (15\%), Meerhout (18.3\%), Roeselaere (15\%), Sint-Niklaas (17.1\%), Stekene (16.1\%), Temse (15.3\%) and Turnhout (17.5\%) to which were added Denderleeuw (26.2\%), Ninove (40\%), Schoten (20.8\%) and Stabroek (20.2\%). That electoral upturn was translated into seats. While the Vlaams Belang was running in far fewer municipalities than in 2012, it took far more seats: 355 out of the 4,175 in the municipalities where it was present (7,385 in Flanders).This result reversed the spiral of defeat the party had been stuck in for ten years. The question is therefore whether it had a cyclical dimension or whether it inaugurated a fourth political and electoral life for the Flemish Extreme Right. The 2019 triple vote delivered a clear answer: The Vlaams Belang is back: in Flanders, it captured not less than $18.6 \%$ and eighteen seats at the federal level.

\subsection{Electoral Geography}

The transformations of the Vlaams Blok's electoral geography in the municipal elections from 1982 to 2018 reveal several dynamics. In 1982 (Figure 1) and 1988 (Figure 2), the party's limited presence and results revealed it existed in the form of an archipelago, almost exclusively around Antwerp. The disproportion in these results was even more striking between Antwerp and the other municipalities in 1988 than in 1982.

In 1994 (Figure 3) and 2000 (Figure 4), two new dynamics emerged. The first 


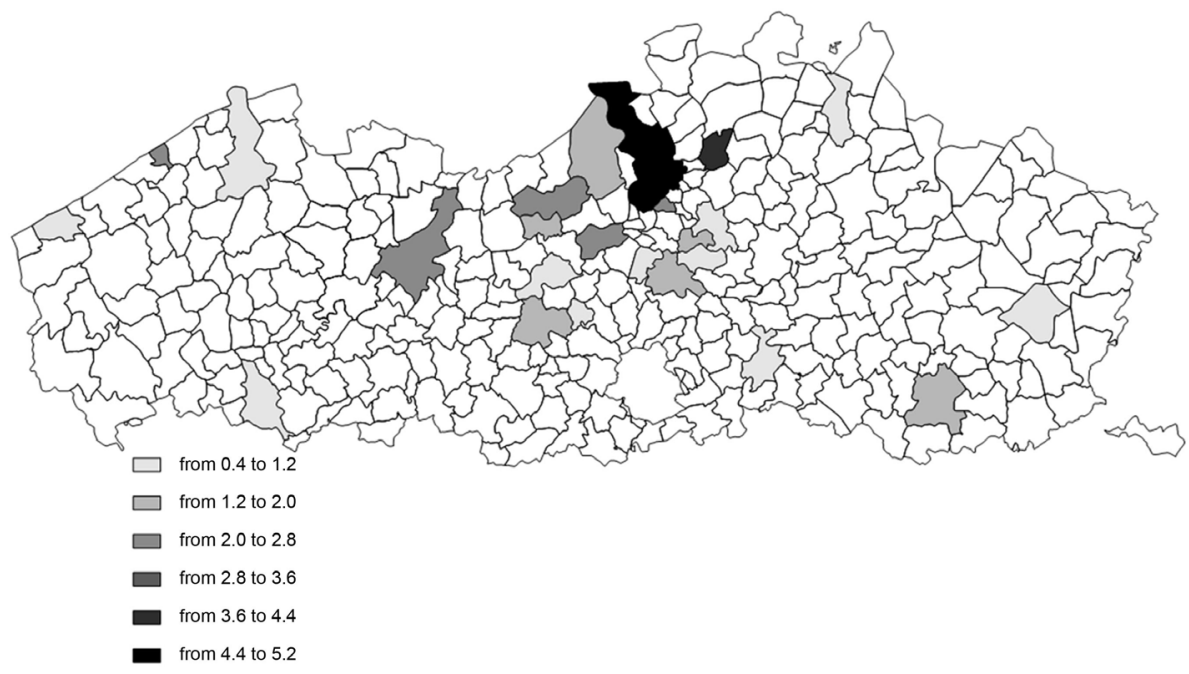

Figure 1. Electoral geography of the Vlaams Blok at the local elections (1982).

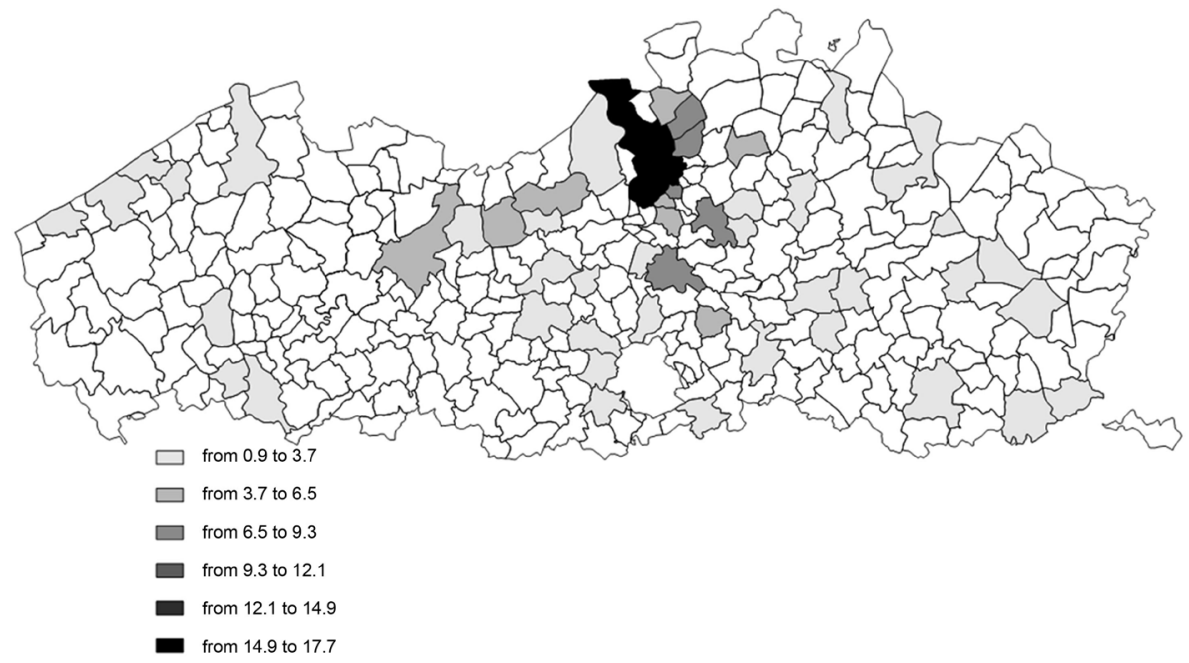

Figure 2. Electoral geography of the Vlaams Blok at the local elections (1988).

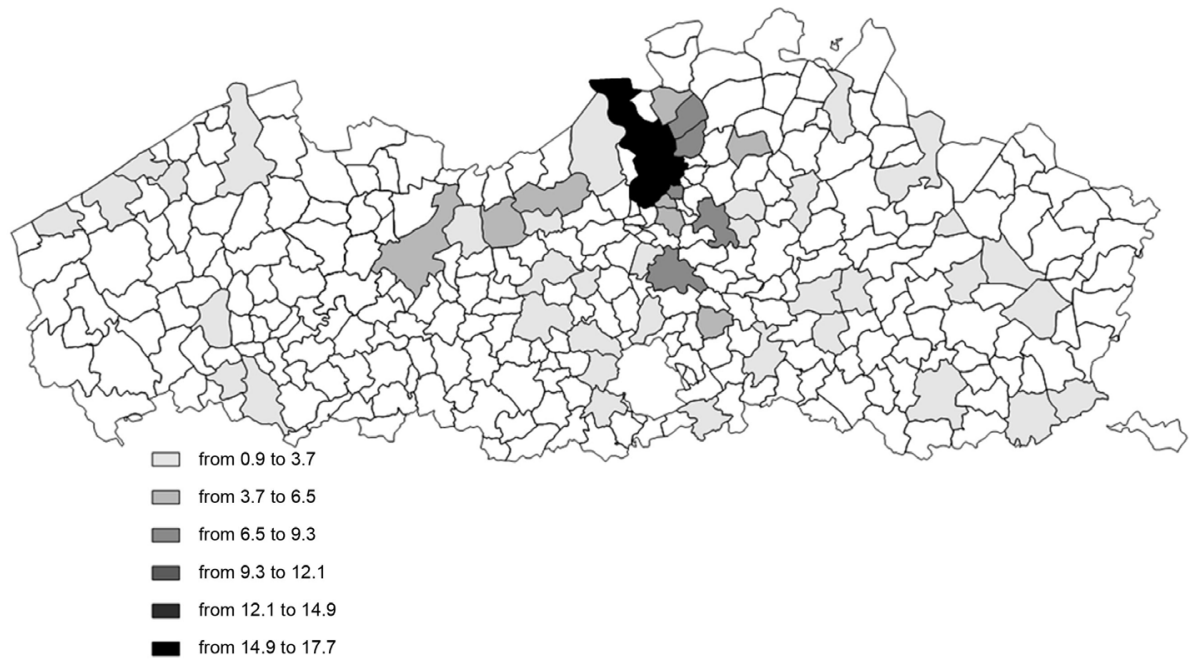

Figure 3. Electoral geography of the Vlaams Blok at the local elections (1994). 


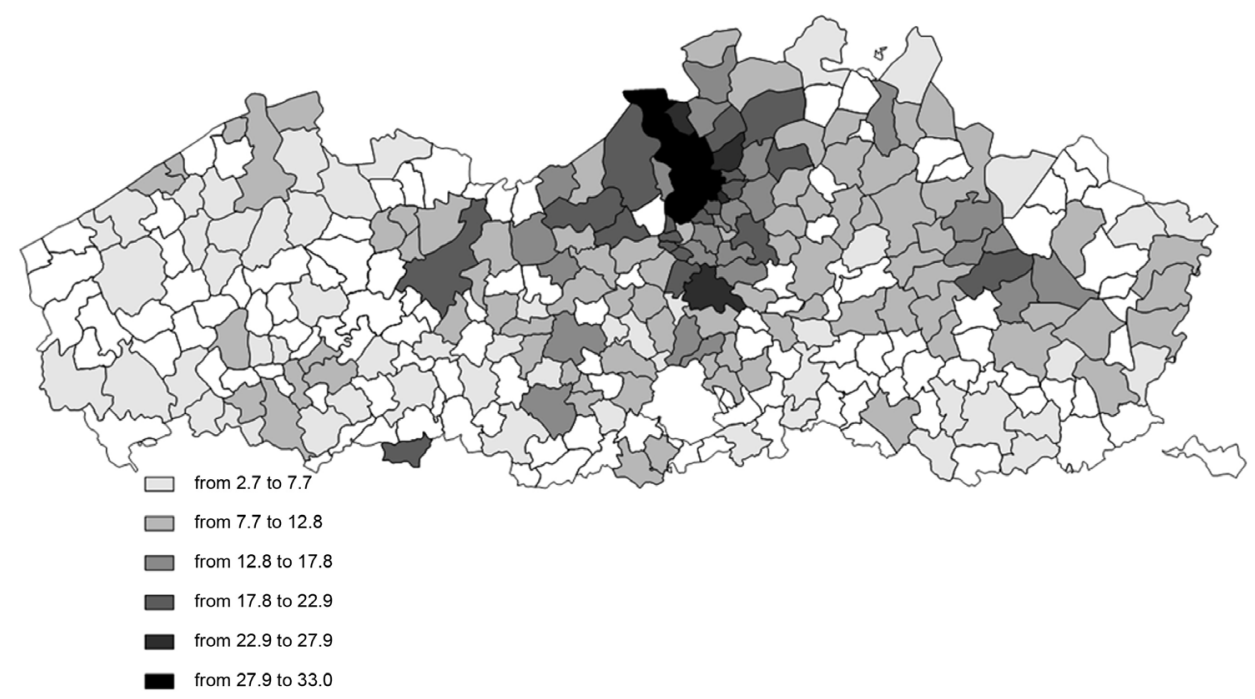

Figure 4. Electoral geography of the Vlaams Blok at the local elections (2000).

was dissemination, not only in terms of lists filing but also in terms of electoral performance. The Vlaams Blok had achieved significant results in many municipalities in the Antwerp province and surrounding areas: in the east, west and south of the said province. This percolation effect continued in 2000. The electoral performance was even more striking as the municipality was close to Antwerp. On the other hand, however, the Vlaams Blok remained a non-actor or a minimal/modest actor in the Western Flanders hinterland, in the south and northwest of the Limburg and in the East of the Flemish Brabant.

In the history of the Flemish Far Right, the diffusion effect from Antwerp in the presentation of a list and in the level of results reached its peak in the 2006 municipal elections (Figure 5). Nevertheless, this Antwerp tropism was tempered by another observation. From now on, on the periphery of this core, the Vlaams Belang obtained a number of convincing results: on the Belgian coast at Bruges and Oostende in particular, in the centre of the Limburg at Beringen and Leopoldsburg for instance and at the southern border of Western Flanders at Kortrijk and its periphery.

The 2012 elections electoral geography (Figure 6) illustrates the dramatic contraction and tentative transition: Antwerp remained important but in a less dramatic way than in the previous five elections. This transition was confirmed in 2018 (Figure 7): the Flemish Far Right remained the most present in the Province of Antwerp, but the city of Antwerp tropism had disappeared and its influence was less marked. A new point of influence is now being established from the Ninove municipality (Eastern Flanders) and, to a lower extent, in Western Flanders, around Kortrijk and Roeselare.

\subsection{Power}

Whatever the result it achieved, the Vlaams Blok and then Vlaams Belang never managed to gain power at municipal level. Contrary to Erk's expectations (2005: 


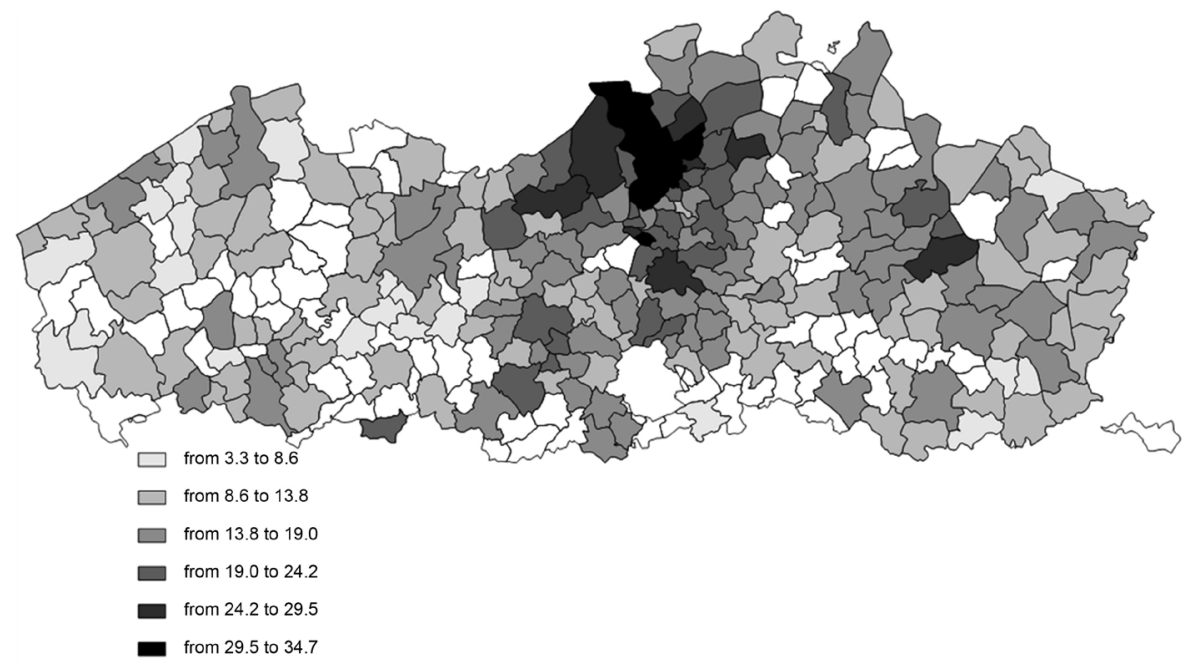

Figure 5. Electoral geography of the Vlaams Belang at the local elections (2006).

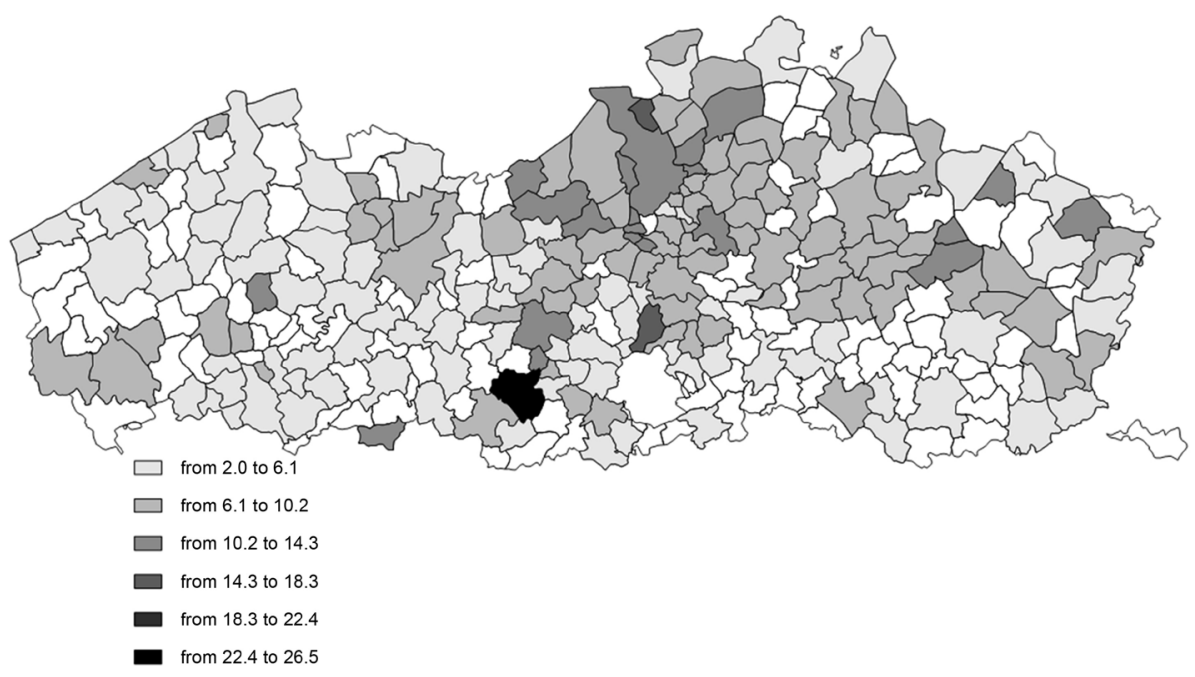

Figure 6. Electoral geography of the Vlaams Belang at the local elections (2012).

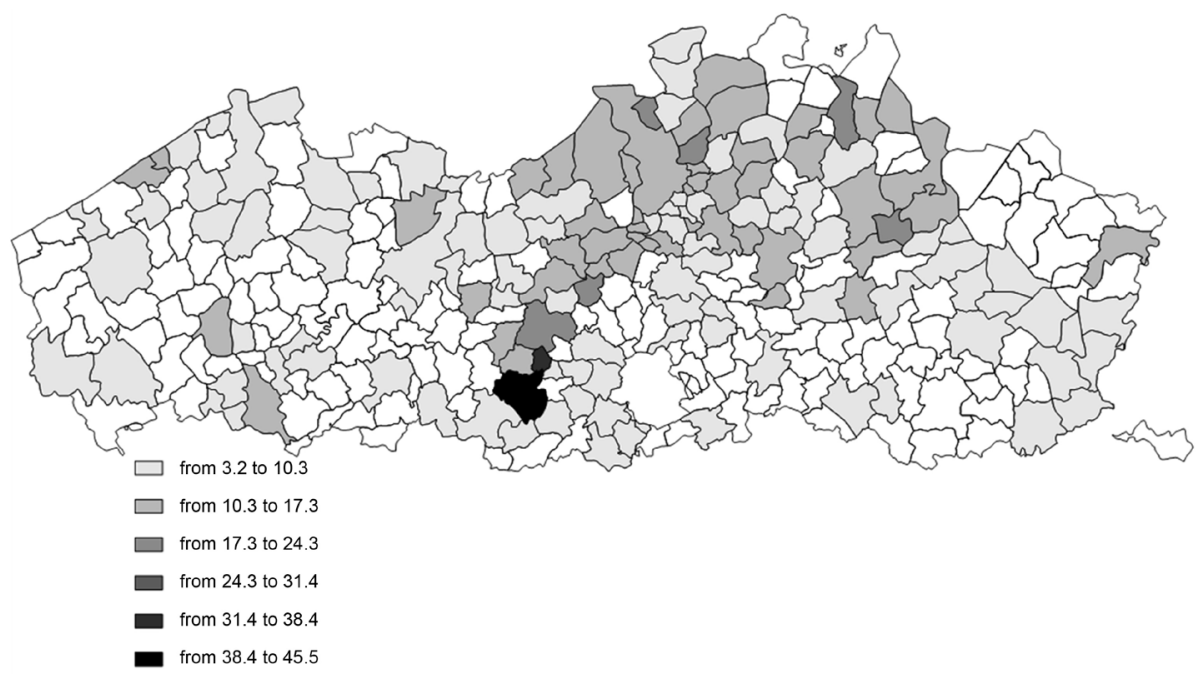

Figure 7. Electoral geography of the Vlaams Belang at the local elections (2018). 
p. 500), the name change did not allow the Vlaams Belang to enter municipal Authorities. The Flemish democratic parties applied a principle known to them as the cordon sanitaire (Coffé, Heyndels, \& Vermeir, 2007). This cordon sanitaire has nevertheless been, and still is, under pressure, for three main reasons. The first, which peaked in 2004-2006, deals with the electoral level the party achieved. With $24 \%$ of the votes cast in regional elections and very high results in many municipalities in 2006, the effectiveness of the cordon sanitaire and even the possibility of maintaining it have been questioned both in the political world and among some scientists. After 2006, with the view of the Flemish Extreme Right's electoral collapse, this argument faded.

More recently, new questions have emerged. Given the fragmentation of the political landscape in municipalities and at the federal level, the immunisation of the Vlaams Belang's seats made it difficult to establish a number of majorities and imposed unexpected coalitions. In 2018, the majority achieved in Antwerp after very long negotiations brought together the N-VA, the liberals (OpenVLD) and the socialists (sp.a), despite a systematically anti-socialist communication axis in the Flemish nationalist leadership. That same year, one municipality attracted tremendous attention: Ninove. The list sponsored by the Vlaams Belang-Forza Ninove-won $40 \%$ of the votes and 15 of the 33 seats. Faced with failure to form a coalition, N-VA's local leader agreed to string up a majority with the other democratic parties. However, the N-VA's leadership did not validate this choice and excluded the councilor.

This illustrates the tension in the field of the cordon sanitaire, particularly for N-VA. Finally, while twelve Radical Right-Wing Parties have been or are into power-or support a government from outside-in Europe, the tension on the Vlaams Belang's exclusion is stronger in a context where going into power for European Radical Right-Wing Parties has become rather common (Ivaldi, 2019).

\section{Conclusion}

The analysis of the Vlaams Blok/Vlaams Belang's electoral performance at local elections can teach several lessons. Despite the major difficulties for a new party, with a more exacerbated polarity than in centripetal parties to achieve being an effective actor in local elections, we do not observe any discrepancy with the dynamics highlighted in national elections. The weight of local issues and the impact of personalization in communal elections did not prevent the Vlaams Blok from overcoming the obstacle and becoming a major party at the municipal level. The achievement is all the more notable as the Vlaams Belang's crucial political messages-rejection of the other and the advent of a Flemish Republic-do not easily fit with the competences of the municipalities in Belgium.

At the 1982 and 1988 municipal elections, the Vlaams Blok was primarily an Antwerp party. From Antwerp from the commune's point of view, and from Antwerp in relation with a diffusion process, which in 1988, took place essentially in the Antwerp province communes. The lists and results' dissemination 
phenomenon deepened considerably after the November 1991 national elections. In line with the continuous surge in national election results, the Vlaams Blok improved its coverage rate and electoral performance in the 1994, 2000 and 2006 local elections. As seen above, the Vlaams Belang reached its pinnacle in the 2004 regional elections. At the local level, it climaxed two years later.

For its part, the 2012 municipal election confirms the decline highlighted in the 2007 and 2010 legislative elections and the 2009 regional election. This decline affects the ability to submit lists to voters and refers to the results obtained in the municipalities where it is present.

To a large extent, these elements attest to the absence of a notability dimension in the Flemish Extreme Right's results, which is not very greatly affected by the local vote. In this light, it would tend to confirm the thesis of the trend towards the nationalization of communal elections. Nevertheless, the 2018 elections still bear witness to the extent to which Flemish Christian Democrats are locally rooted (Delwit, 2019) in a way that is not comparable to CD\&V results in regional and national elections. The Vlaams Belang's progress and decline owe more to the party's image and general state than to its institutionalisation in municipalities. It should also be noted that communal elections had an impact on the party's image and overall state. In 1988, the score achieved at Antwerp $-17.7 \%$ and 10 seats out of $55-$ generated a lot of comment in the media and in the political world, allowing the party to move outside its confinement zone. Besides, an early translation took place in the 1989 European elections, before the 1991 legislative elections greatly amplified this movement. In 2006, the Vlaams Belang achieved its best results in local elections by far. For all that, the commentary and analysis focused on the "Antwerp failure", severely affecting the party's image and leadership. One year later, the Vlaams Belang lost five percentage points in the parliamentary elections, anticipating a collapse in three stages: 2009, 2010 and 2014.

The result of the 2018 local election suggested the hypothesis of a new crystallization occurring during the communal elections. The Vlaams Belang put a stop to its electoral decline in this election. The average performance in the municipalities where it was introduced is significantly higher than in 2012. In the provincial elections that took place on the same day, this rebound was also observed. At the legislative, regional and European elections of May 2019, the Vlaams Belang confirmed its recovery. Hence, three municipal elections have been proved to be decisive political moments in the political development of the Flemish Extreme Right. Rather than offering apossible institutional or political wall, local elections proved to be milestones in the Vlaams Belang's lifespan (Pedersen, 1982). In three cases, local elections created a spillover effect for the Vlaams Belang; either as some leverage for an electoral breakthrough or upturn (1988 and 2018) or for a electoral collapse (2006). In 1988 and 2018, the Vlaams Belang victory in some communes also created a contagion effect. In 1988, their victory in the city of Antwerp generated this effect first in the province of Ant- 
werp and then in the other Flemish provinces. In 2018, the breakthrough in the commune of Ninove generated this effect in all communes surrounding Ninove at the 2019 National and Regional Elections, where the Vlaams Belang captured nearly $30 \%$.

\section{Conflicts of Interest}

The author declares no conflicts of interest regarding the publication of this paper.

\section{References}

Adam, I., \& Deschouwer, K. (2016). Nationalist Parties and Immigration in Flanders: from Volksunie to Spirit and N-VA. Journal of Ethnic and Migration Studies, 42, 1290-1303. https://doi.org/10.1080/1369183X.2015.1082285

Akkerman, T., de Lange S., \& Rooduijn M. (2016). Radical Right-Wing Populist Parties in Western Europe: Into the Mainstream? New York: Routledge. https://doi.org/10.4324/9781315687988

Bennett St., E., \& Tuchfarber, A. (1975). The Social-Structural Sources of Cleavage on Law and Order Policies. American Journal of Political Science, 19, 419-438. https://doi.org/10.2307/2110537

Betz, H. G. (1994). Radical Right-Wing Populism in Western Europe. London: Palgrave. https://doi.org/10.1007/978-1-349-23547-6

Brack. N. (2018). Opposing Europe in the European Parliament: Rebels and Radicals in the Chamber. London: Palgrave. https://doi.org/10.1057/978-1-137-60201-5

Brems, E. (2006). Belgium: The Vlaams Blok Political Party Convicted Indirectly of Racism. International Journal of Constitutional Law, 4, 702-711. https://doi.org/10.1093/icon/mol032

Cetrà, D., \& Liñeira, R. (2018). Breaking up within Europe: Sub-State Nationalist Strategies in Multilevel Polities. Journal of Common Market Studies, 56, 717-729. https://doi.org/10.1111/jcms.12710

Coffé, H., Heyndels, B., \& Vermeir, J. (2007). Fertile Grounds for Extreme Right-Wing Parties: Explaining the Vlaams Blok's Electoral Success. Electoral Studies, 26, 142-155. https://doi.org/10.1016/j.electstud.2006.01.005

Collinge, M. (1981). La poltisation des élections communales: Stratégie des partis politiques en Wallonie. Courrier hebdomadaire du CRISP, No. 917, 1-21. https://doi.org/10.3917/cris.917.0001

de Koster, W., Achterberg, P., \& van der Waal, J. (2013). The New Right and the Welfare State: The Electoral Relevance of Welfare Chauvinism and Welfare Populism in the Netherlands. International Political Science Review, 34, 3-20. https://doi.org/10.1177/0192512112455443

De Wever, B. (1994). Greep naar de macht: Vlaams-nationalisme en Nieuwe Orde: het VNV, 1933-1945. Tielt: Lannoo.

Delruelle-Vosswinkel, N., Noël Fr., Vanlaer, J., \& Vandermotten, C. (1989). Les élections communales du 9 octobre 1988: Évolution des familles politiques et géographie électorale. Bulletin trimestriel du Crédit communal de Belgique, No. 169, 31-49.

Delwit, P. (2005). Les partis régionalistes en Europe. Des acteurs en développement? Brussels: Editions de l'Université de Bruxelles. 
Delwit, P. (2012). La vie politique en Belgique de 1830 à nos jours. Brussels: Editions de l'Université de Bruxelles.

Delwit, P. (2019). La-N-VA et les élections d'octobre 2018: Des aspirations contraries (pp. 1-34). Cahier du Cevipol/Brussels Working Papers.

Delwit, P., \& van Haute E. (2002). L'implosion et la fin d'un parti: La Volksunie. L'année sociale, 13-24.

Dolez, B. (2004). A la recherche de l'abstentionnisme différentiel. Actualité d'une vieille question. Revue française de science politique, 54, 669-680. https://doi.org/10.3917/rfsp.544.0669

Erk, J. (2005). From Vlaams Blok to Vlaams Belang: The Belgian Far Right Renames Itself. West European Politics, 28, 493-502. https://doi.org/10.1080/01402380500085681

Govaert, S. (1992). Le Vlaams Blok et ses dissidences. Le Courrier hebdomadaire du CRISP, No. 1365, 1-41. https://doi.org/10.3917/cris.1365.0001

Heinisch, R., \& Mazzoleni, O. (2016). Understanding Populist Party Organisation: The Radical Right in Western Europe. London: Palgrave. https://doi.org/10.1057/978-1-137-58197-6

Ignazi, P. (1998). The Iron Law of Party Institutionalization. Paper for Delivery at the ECPR Conference.

Ignazi, P. (2003). Extreme Right Parties in Western Europe. Oxford: Oxford University Press.

Ivaldi, G. (2019). De Le Pen à Trump: Le défi populiste. Brussels: Editions de l'Université de Bruxelles.

Ketola, M., \& Nordensvard, J. (2018). Reviewing the Relationship between Social Policy and the Contemporary Populist Radical Right: Welfare Chauvinism, Welfare Nation State and Social Citizenship. Journal of International and Comparative Social Policy, 34, 172-187. https://doi.org/10.1080/21699763.2018.1521863

Kitschelt, H. (1988). Left-Libertarian Parties: Explaining Innovation in Competitive Party Systems. World Politics, 40, 194-234. https://doi.org/10.2307/2010362

Kitschelt, H. (1997). The Radical Right in Western Europe: A Comparative Analysis. Ann Arbor, MI: Michigan University Press. https://doi.org/10.3998/mpub.14501

Klandermans, B., \& Mayer, N. (2001). Militer à l'extrême droite. In P. Perrineau (Ed.), Les croisés de la société fermée. L'Europe des extrêmes droits (pp. 147-162). Paris: l'Aube.

Kriesi, H. (2014). The Populist Challenge. West European Politics, 37, 361-378. https://doi.org/10.1080/01402382.2014.887879

Lipset, S. M., \& Rokkan, S. (1967). Party Systems and Voter Alignments: Cross-National Perspectives. New York: Free Press.

Lubbers, M., Scheepers, P., \& Billiet, J. (2000). Multilevel Modelling of Vlaams Blok Voting: Individual and Contextual Characteristics of the Vlaams Blok Vote. Acta Politica, 35, 363-398.

Marien, S., Dassonville, R., \& Hooghe, M. (2015). How Second Order Are Local Elections? Voting Motives and Party Preferences in Belgian Municipal Elections. Local Government Studies, 41, 898-916. https://doi.org/10.1080/03003930.2015.1048230

Mudde, C. (1995). One against All, All against One! A Portrait of the Vlaams Blok. Patterns of Prejudice, 29, 5-28. https://doi.org/10.1080/0031322X.1995.9970144

Mudde, C. (2002). The Ideology of the Extreme Right. Manchester: Manchester University Press.

Mudde, C. (2017). The Populist Radical Right: A Reader. New York: Routledge. 
https://doi.org/10.4324/9781315514574

Muis, J., \& Immerzeel, T. (2017), Causes and Consequences of the Rise of Populist Radical Right Parties and Movements in Europe. Current Sociology, 65, 909-930. https://doi.org/10.1177/0011392117717294

Müller, J. W. (2016). What Is Populism? Philadelphia, PA: The University of Pennsylvania Press.

Nieuw-Vlaamse Alliantie (2018). Statuten Gecoördineerde versie.

Pauwels, T. (2011). Le Vlaams Blok. In P. Delwit, J. B. Pilet, \& E. van Haute (Eds.), Les partis politiques en Belgique (pp. 219-234). Brussels: Editions de l'Université de Bruxelles.

Pedersen, M. N. (1982). Towards a New Typology of Party Lifespans and Minor Parties. Scandinavian Political Studies, 5, 1-16. https://doi.org/10.1111/j.1467-9477.1982.tb00256.x

Pilet, J. B. (2007). Changer pour gagner? Les réformes électorales en Belgique. Brussels: Editions de l'Université de Bruxelles.

Pilet, J. B., Freire, A., \& Costa, O. (2012). Ballot Structure, District Magnitude and Constituency-Orientation of MPs in Proportional Representation and Majority Electoral Systems. Representation, 48, 359-372. https://doi.org/10.1080/00344893.2012.720880

Reif, K., \& Schmitt, H. (1980). Nine Second-Order National Elections. A conceptual Framework for the Analysis of European Election Results. European Journal of Political Research, 8, 3-44. https://doi.org/10.1111/j.1475-6765.1980.tb00737.x

Spruyt, M. (1995), Le Vlaams Blok et la Nouvelle droite. Le détournement de Gramsci. In H. Le Paige (Ed.), Le désarroi démocratique. L'extrême droite en Belgique (pp. 165-181). Brussels: Labor.

Sternhell, Z., Sznajder, M., \& Ashéri, M. (1989). Naissance de l'idéologie fasciste. Paris: Folio.

Swyngedouw, M., \& Ivaldi, G. (2001). The Extreme Right Utopia in Belgium and France: The Ideology of the Flemish Vlaams Blok and the French National Front. West European Politics, 24, 1-22. https://doi.org/10.1080/01402380108425450

Van Haute, E., \& Gauja, A. (2015). Party Members and Activists. New York: Routledge. https://doi.org/10.4324/9781315722214

van Haute, E., \& Pilet, J. B. (2006). Regionalist Parties in Belgium (VU, RW, FDF): Victims of Their Own Success? Regional \& Federal Studies, 16, 297-313. https://doi.org/10.1080/13597560600852474

Vlaams Blok (1992). Immigratie: De oplossingen: 70 voorstellen ter oplossing van het vreemdelingenprobleem. 